\title{
小規模生活単位型高齢者居住施設における滞在場所の多様性に関する考察 A STUDY ON FORMATION OF VARIOUS STAYING PLACES BY THE RESIDENTS IN ELDERLY FACILITIES WITH SMALL GROUP UNITS
}

\author{
橘 弘志* \\ Hiroshi TACHIBANA
}

\begin{abstract}
This study aims to discuss the qualities of common spaces of the elderly facilities with small care units that effects on the residents' daily life, especially for the severely frail elderly, from the viewpoint of meanings and values of various staying places of the residents formed in the spaces. For this objective, 3 types of facilities were surveyed, those were 2 unit-type nursing homes and 1 group home for the elderly with dementia, by means of mapping of activities of the residents/ care staffs, behavior observation. The findings are follows:

1) Quality of life of the elderly residents is influenced by formation of various staying places. Without various staying places, lives of the severely frail residents tends to be passive and monotonous. 2) It is important that there are not only many staying places but also various staying places qualitatively. They afford various social relations of the residents, and stimulate various activities, and contribute to enlarging their sphere of life. 3) Variety of staying places brings different effect to slight residents and severe residents. The former can use various places depending on their situation properly, and the latter can select particular places adapted to them.
\end{abstract}

Keywords: The elderly, Unit-type nursing home, Group home, Residents' staying place, Being in place, Severely frail residents

高齢者，ユニット型特別養護老人ホーム，グループホーム，滞在場所，居方，重度入居者

\section{1. はじめに}

2002 年にユニット型（当時は小規模生活単位型）の特別養護老 人ホーム (以下、特養) が制度化され、10 年が経過した。この間、 ユニット型特養の整備は進み、2009 年には全特養の $28.9 \%$ にユ ニット型が導入されるようになっている主 1 。集団ケアを前提とし ていたかつての従来型施設にくらべ、少人数での個別ケアを目指す ユニット型は、生活の場としての環境づくりを目的とするものであ る。生活単位を小規模化し、一人ひとりの身の置きどころとしての 個室を設え、小集団による共同での生活が完結するように共同生活 室や浴室をユニット内に設けることで、「住まい」としての質は確 実に向上しているように思われる。

こうしたユニット型が制度化される前後にかけて、特養を中心と する高齢者居住施設を対象とした研究が数多く行われ、ユニットケ アの実態や入居者の生活に与える効果はさまざまに検証されてきた 注2。これらの研究の成果はユニットケアの制度化を後押しし、整 備を促進させることに寄与したと考えられる。しかし、ユニット型 施設の平面計画のあり方については十分明らかにされておらず、整 備実態はかなり多様な状況となっている注3。形だけユニット型を 取り入れながら、従来の集団処遇に近いケアが行われていることも 指摘されている注 4 。

近年、ユニット型施設を対象にした研究は、アンケート等をもと
に全体的な整備状況を捉えようとするものが多く、現場の実態から 入居者の生活の質を捉えようとする研究は、グループホーム（以下、 $\mathrm{GH}$ ) などの小規模施設にその中心が移行している傾向がある。そ れらの研究によって、空間構成や運営が入居者の生活の様態に大き く影響を与えていること主 5 、小規模な空間のなかに多様な場を設 けることで、生活の多様性・個別性を高めることの重要性注 6 など、 さまざまな知見が得られている。特養も $\mathrm{GH}$ も、要介護状態の高 歯者のための生活施設であり、入居者 10 人程度の小規模な生活単 位を形成しょうとする点で共通しており、制度としては異なるもの の、環境に対する知見は重なるところが大きいだろう。

こうした施設では今後、入居者の重度化がますます進行すること が予測される。入居者の重度化に伴い、滞在場所が限定されて生活 が単調になりやすいこと注 $7 、 一$ 度形成された一人ひとりに固有の 居場所は入居者の自立度の変化などにはさほど影響を受けない注8 などの知見が得られている。そのような状況にユニット型施設がど のように対応していくのかは、検討すべき重要な課題である。

国の補助が打ち切られた現在注 9 、特養のような大規模施設の新 規建設は、それほど増えないことが予想される。しかし、施設の建 て替えや改修によって、従来型の施設からユニット型への変換は、 むしろこれからが本格化していくだろう。単にマニュアル通りのユ ニット化ではなく、入居者の生活の質が高められ、維持されるよう 
な施設空間のあり方を見据える必要がある。

このような視点から、本研究は小規模生活単位型の要介護高龃者 向けの居住施設を対象とし、現場での実態調査を通して、生活ユニッ トのつくりと入居者の生活との関わりを分析することにより、今後 ますます重度化する入居者の生活の質を高めるための空間のあり方 についての知見を得ようとするものである。施設空間における入居 者の滞在の様態を定量的・定性的に分析し、滞在場所が入居者の生 活の質に与える影響を捉えることにより、ユニット内外に多様な滞 在場所を構築することの効果とその意味を明らかにすることを目的 とする。

\section{2. 調査概要}

調査対象として、既往の建築的知見を活かして設計された比較的 新しい事例 $(\mathrm{A}$ 施設)、ユニット型特養の制度化以前からいち早く 取り組んできた先駆的事例 (B 施設)、そして小規模ながら多様な 空間構成を有する $\mathrm{GH}(\mathrm{C}$ 施設)、の 3 施設とした。

$\mathrm{A}$ 施設は 2007 年に開設した平屋建てのユニット型特養である。 空間的独立性の高いユニットを中央廊下で結びつける空間構成であ り、すべての居室・リビング・廊下が直接外部に面している。1 ユ ニット $8 \sim 9$ 人とし、居室は、雁行させた片廊下型の北側に直線 的に配置され、廊下の南側あるいは突き当たりにリビング+キッチ ンが設けられている。

$\mathrm{B}$ 施設は 2000 年に開設し、ユニットケアのモデル施設となった 特養である。 3 階建ての $2 \cdot 3$ 階部分が居住空間となっており、各 フロアとも、共有の食堂ホールを中心に、6〜8 人の 4 つのユニッ トが取り巻いている。居室は廊下を挟んでなかばリビングを囲むよ うに配置されている。各ユニットは隣接ユニットと直接廊下が連結 されており、ユニット同士の境界は、後付けの格子状の建具によっ
て仕切られている。

C 施設は 2007 年開設の、2 ユニットからなる GHである。1 ユニッ 卜定員 9 人をさらに 4 人と 5 人に分け、その小グループごとに和 室やダイニングなどの共用空間を個別に設けている。全体に和風の 空間構成で、共同生活室も和室の続き間となっており、和室同士お よびDK は互いにフスマで仕切られている。

調査は、平日の 7 時〜 19 時の間、15 分おきに各入居者および スタッフの滞在場所をプロットし、それぞれの行為の様子を記入し た。ユニットごとに 1 名ずつの調査員を配置し、施設の全入居者 を特定した上で、記録の対象としている。各施設で得られた全 49 回の時間断面のデー夕をもとに分析をおこなった。

表 1 調査対象施設概要

\begin{tabular}{|c|c|c|c|}
\hline & A施設 & B施設 & C施設 \\
\hline 種別 & 特別養護老人ホーム & 特別養護老人ホーム & 認知症高齢者グループホーム \\
\hline 開設 & 2007年 & 2000年 & 2007年 \\
\hline 定員 & 50名+ショート6名 & 50名+ショート20名 & 18名（9名×2ユニット） \\
\hline 面積 & $3656 \mathrm{~m}^{2}$ & $3647 \mathrm{~m}^{2}$ & $745 \mathrm{~m}^{2}$ \\
\hline $\begin{array}{c}\text { ユニット面積 } \\
\text { (一人当り) }\end{array}$ & $\begin{array}{r}312 \sim 315 \mathrm{~m}^{2} \\
\left(37 \sim 41 \mathrm{~m}^{3}\right)\end{array}$ & $\begin{array}{r}150 \sim 220 \mathrm{~m}^{2} \\
\left(25 \sim 27 \mathrm{~m}^{2}\right)\end{array}$ & $\begin{array}{l}360 \cdot 361 \mathrm{~m}^{2} \\
\left(40 \mathrm{~m}^{2}\right)\end{array}$ \\
\hline 構造 & $\mathrm{RC} 1$ 階建て & RC3階建て & 木造1階建て \\
\hline 調査日 & 2009年11月15日 & 2009年11月22日 & 2010年11月10日 \\
\hline 調査対象 & 48人 & $49 人$ & 18人 \\
\hline 平均要介護度 & 3.17 & 3.87 & 3.11 \\
\hline
\end{tabular}

表 2 入居者属性 (単位: 人)

\begin{tabular}{|l|c|c|c|c|c|c|c|c|c|c|c|c|c|}
\hline & & \multicolumn{9}{|c|}{ 性別 } & \multicolumn{5}{|c|}{ 要介護度 } & \multicolumn{5}{|c|}{ 年齢 } \\
\hline & 合計 & 男 & 女 & 1 & 2 & 3 & 4 & 5 & $\sim 64$ & $\sim 74$ & $\sim 84$ & $\sim 94$ & $95 \sim$ \\
\hline A施設 & 48 & 12 & 36 & 1 & 13 & 17 & 11 & 6 & 1 & 3 & 15 & 23 & 6 \\
\hline B施設 & 49 & 12 & 37 & 2 & 3 & 11 & 16 & 17 & 2 & 4 & 16 & 20 & 7 \\
\hline C施設 & 18 & 2 & 16 & 3 & 1 & 6 & 7 & 1 & 0 & 1 & 3 & 10 & 4 \\
\hline
\end{tabular}
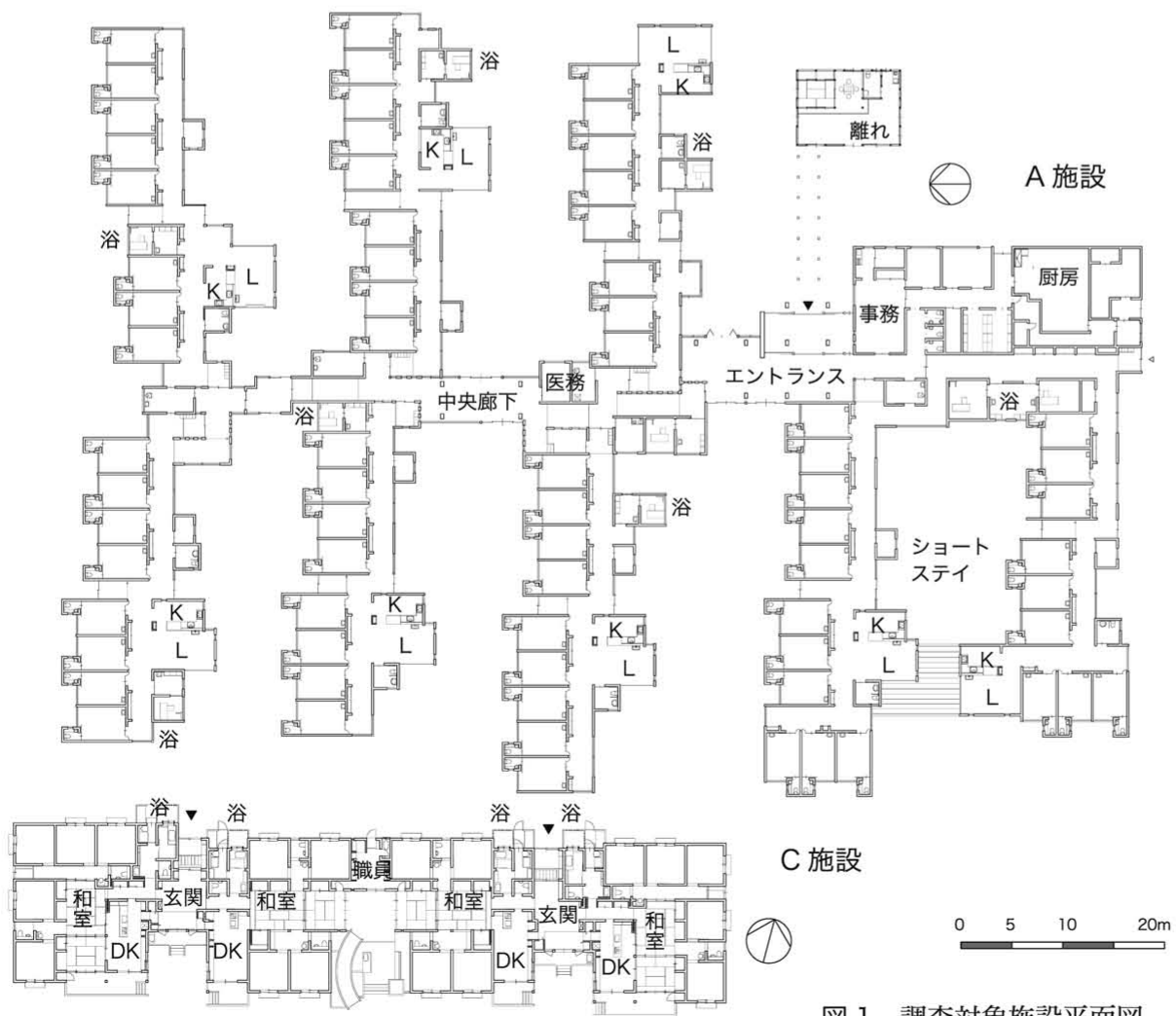

図 1 調査対象施設平面図
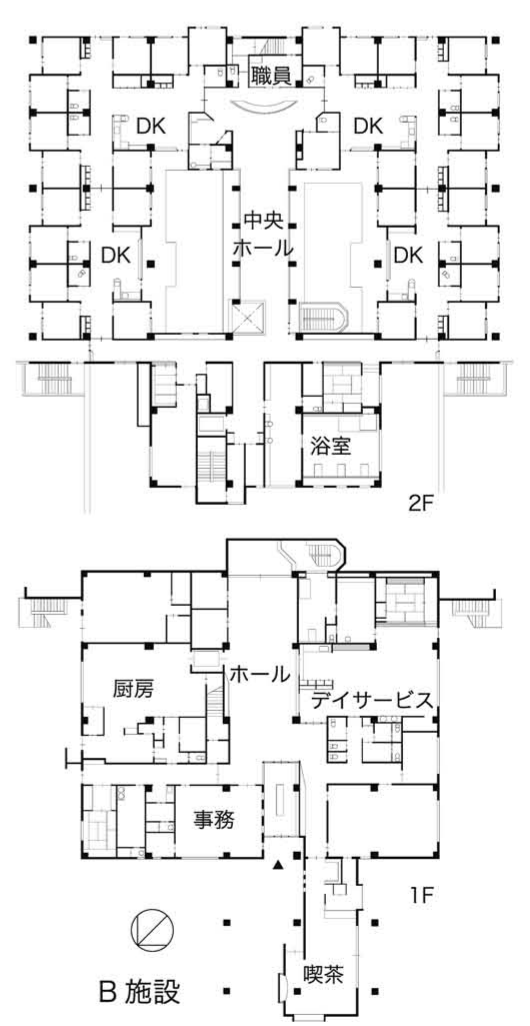


\section{3. 入居者の滞在場所と過ごし方}

図 2 に、各施設における全入居者の滞在場所を、居室・リビング等・ ユニット内・他ユニット・ユニット外、の 5 領域に分けて、その平 均の割合を示す（図 2)。A・B 施設は居室の滞在が $50 \%$ 弱と、似た 傾向を示しているが、B施設のほうがユニットの外に滞在する割合 が多少高い。C 施設は他 2 施設に比べ居室での滞在時間が 2 割程度 とかなり短く、そのぶんリビング等での滞在が顕著に高くなってい ることが特徴である。

要介護度別にみると（図 3)、A 施設では要介護 5 の重度入居者、 および 1 〜 の軽度入居者の居室滞在が長く、いつぽう要介護 3 4 の中度入居者はリビング等の滞在がやや長い。B 施設は要介護度 による滞在場所の違いはそれほど大きくないが、要介護度が高くな るとともに少しずつ居室滞在が減り、リビングでの滞在が増えてい る。C 施設は、軽度入居者が最も居室に滞在する時間が長く、中度 〜重度になると一日の 7 割以上の時間をリビング等で過ごしている。 全体に、軽度ほど全体に居室での滞在が長くなる傾向は共通してい るが、中度以上となると、A 施設では重度化すると居室に滞在する のに対し 注 $10 、 \mathrm{~B} ・ \mathrm{C}$ 施設ではむしろリビング等に滞在するようにな るという差異がみられた。

次に、共用空間における入居者の過ごし方を、「無為」「プログラ ム行為」「個人的活動」「グループ活動」「交流」「自然な集まり」の 6 種類に分け、その割合を示す注 11 (図 4)。A 施設とB 施設は比較 的似た傾向を示しており、無為とプログラム行為で全体の 8 割近く を占める。いつぽう C 施設は無為・プログラム行為を合わせて 4 割 強であり、個人的活動や交流、自然な集まりといつた自主的な過ご し方が多い。共用空間での滞在割合が $\mathrm{A} ・ \mathrm{~B}$ 施設に比べ高いことを 考えると、自主的な過ごしたり他者と関わりながら過ごす時間は、 このグラフの結果以上に多いことになる。

要介護度別にみると（図 5)、要介護度が高くなるほど、無為やプ ログラム行為の割合が高くなり、生活が受動的になっていく傾向は、 3 施設とも共通している。A 施設では、軽度・中度ともに無為+プ ログラム行為で 7 割近くを占める。重度ではさらに無為の割合が高 くなり、共用空間で過ごす時間の 9 割が無為十プログラム行為で占 められる。とくに要介護 5 は、共用空間での滞在時間も短いため、 自主的な活動はきわめて限られていることになる。B施設では、軽 度にほとんど無為が見られない。重度になるにつれ、A施設と同様 に無為が増加するが、自主的な活動や他者との関わりは A 施設より 若干多い。C 施設でも、軽度は無為に過ごすことがなく、自主的な 活動や他者と関わりの割合がかなり高い。要介護度が高くなるにつ れ無為が増えるものの、A・B 施設に比べるとその割合は低く、重 度になっても多様な活動や関わりが行われている。C 施設はリビン グ等での滞在時間も長く、集まって生活することの利点を活かした 過ごし方がなされていることが推察される。

\section{4. 滞在場所の数}

食事や入浴・排泄などのプログラム行為を行う以外で、入居者が 一定時間以上滞在している場所の数をカウントした主 12 (図 6)。

滞在場所数の平均值は、大きい順に $\mathrm{C}$ 施設 $>\mathrm{B}$ 施設 $>\mathrm{A}$ 施設となっ た。A施設の 2.0 という值は、滞在場所がほとんど「自分の居室」と「リ ビング」だけに限られていることを示す。要介護度別にみると、A

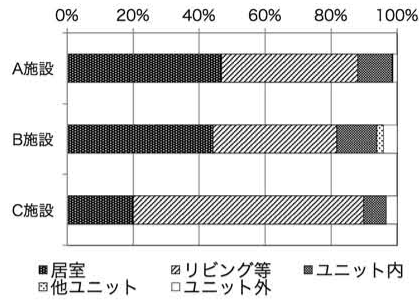

図 2 入居者の滞在場所

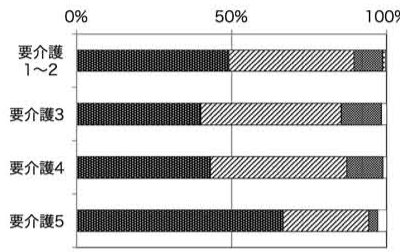

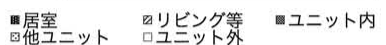

0\% $\quad 50 \%$

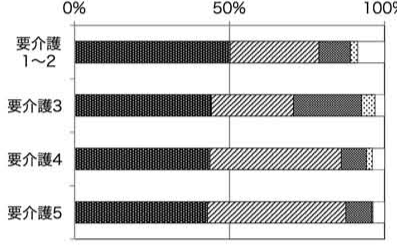

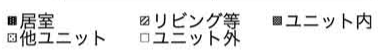

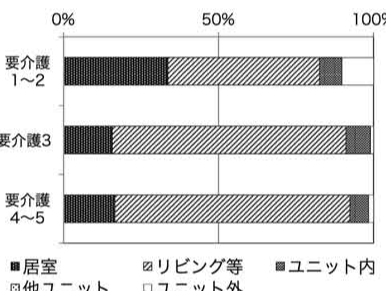

図 3 要介護ごとの滞在場所 上：A、中：B、下：C施設

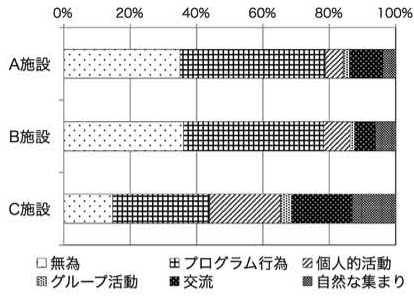

図 4 共用空間での過ごし方

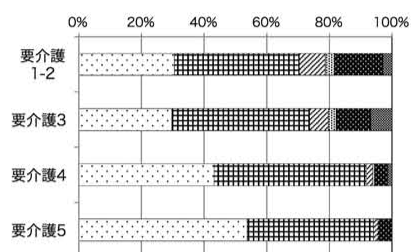

ロ無為ーブ活動 ロプログラム、個人的活動

$\begin{array}{llllll}0 \% & 20 \% & 40 \% & 60 \% & 80 \% & 100 \%\end{array}$

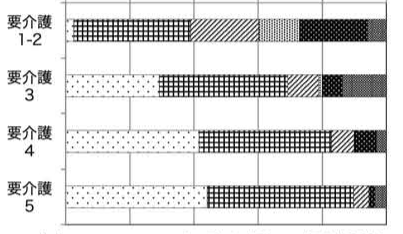

$\begin{array}{lll}\text { 口無為 } & \begin{array}{l}\text { ロプログラム行為涸人的活動 } \\ \text { 自然な集まり }\end{array}\end{array}$
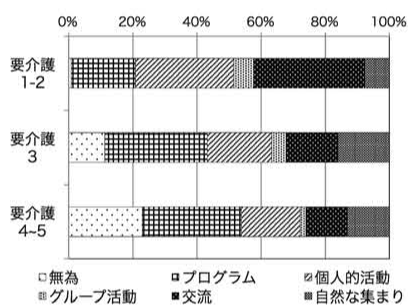

図 5 要介護ごとの過ごし方

上：A、中：B、下：C 施設

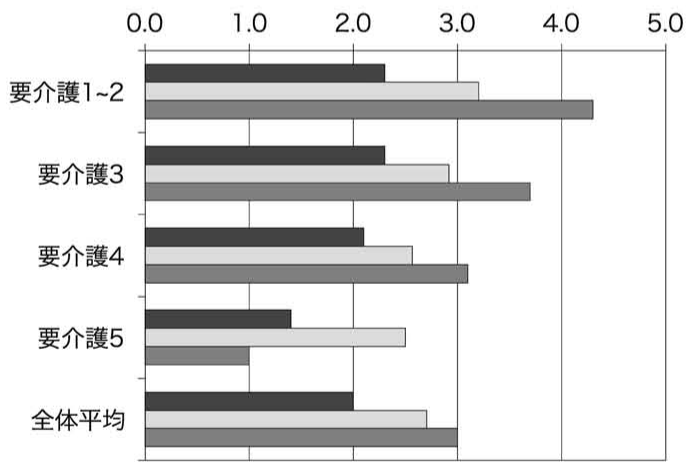

田施設

$\square \mathrm{B}$ 施設 回施設

図 6 入居者の居場所数

施設は要介護 1 ～ 2 から 4 まで、その值に大きな差はみられない。 $\mathrm{B} \cdot \mathrm{C}$ 施設では、軽度ほど滞在場所数が多く、重度化するにつれ減 少している。B施設では要介護 $1 \sim 3$ の滞在場所数はほぼ 3 であり、 「自分の居室」「リビング」以外に、少なくとももう一カ所は滞在場 所があると言える。要介護 5 でも 2.5 と、A 施設の軽度より大き い值である。C 施設はさらに多くの滞在場所があり、要介護 1 ～ 2 では 4 力所以上、要介護 4 でも 3 力所以上の滞在場所が見られる。 この結果がすべて主体的に選択された場所とは限らないが、滞在場 所数が多いことは、小規模な生活単位の中で、居室とリビングの往 
復だけではない生活が行われていることを示している。

\section{5. 滞在場所における過ごし方}

次に、場所ごとの過ごし方から、滞在場所の質に注目する。表 3 は、要介護度別に、共用空間の各場所の使われ方とその頻度を、円 グラフで示したものである。以下、各施設の特徵を挙げる。

(1) A 施設

他施設と比べ全体に、入居者の滞在場所は限定されている。中度 〜軽度では、メインの滞在場所であるリビング以外にも、複数の滞 在場所が観察された。リビングは食事プログラムのほか、交流や自 然な集まり、個人的活動の場として、多様な意味を持った滞在場所 となっている。廊下ベンチは軽度より中度で多く使われており、主 に他者と関わる空間となっている。また数は少ないが、他ユニット を訪れたりユニット外での活動に参加する例が見られる。重度にな ると、リビング以外での滞在はほぼ見られず、唯一の滞在場所であ るリビングはほとんど無為とプログラム行為で占められている。重 度入居者にとっては、居室で一人でいるか、リビングでぼんやりと 過ごすか、という二者択一の単調な生活になりやすい環境と言える。 現状では、リビングで中〜軽度入居者の活動や交流が行われており、 重度入居者も少なくとも同じ空間に居合わせていられるが、今後入 居者が全体的に重度化した場合、他者の活動や関わりに触れられる 機会がさらに減少する可能性がある。

(2) B 施設

軽度の入居者には、ユニット内外に多様な滞在場所が存在してい る。リビングはプログラム以外でも交流の場として、キッチンは一 人やグループでのお手伝い活動の場として、廊下ベンチは他者と自 然に居合わせる場として、それぞれ特徴のある過ごし方がなされて いる。ユニット外では、他ユニットに赴いて他者と関わったり、中 央ホールで一人で過ごしたりしている。中度でも、多少減少するも のの、やはり複数の滞在場所を見て取ることができる。リビングは 無為やプログラム行為が多くを占めるようになるが、廊下のベンチ は軽度よりも使用されるようになり、他者と自然に居合わせる場所 となっている。重度では滞在場所数はさらに減少し、リビングは無 為とプログラム行為で占められるようになるが、ここだけに滞在場 所が限定されていない。廊下ベンチでは他者と居合わせるなど、直 接のコミュニケーションが困難であっても、間接的に他者との関わ りをもつことのできる場となっている。また、中央ホールに連れて きてもらって、一人で過ごす例もみられた。

\section{(3) C 施設}

要介護度にかかわらず、多くの滞在場所が見られる。軽度の主な 滞在場所はメインの和室であり、そこに比較的長時間滞在し、他者 と関わったり活動する拠点となっている。続き間の奥の部屋で食事 をとったり他者と関わる入居者もいる。キッチンでは自主的にお手 伝いなどの作業が行われている。ユニット内のもう一つの続き間は、 おそらく選択的に用いられており、数人でグループ作業を行ったり 一人で過ごす空間となっている。さらに散歩に行ったり、ゴミ出し をしたりなど、外部空間にも生活が広がっている。中度〜重度の入 居者も同様に、続き間やダイニングを拠点としながら、いくつもの 滞在場所が見られ、交流や他者との居合わせ、自主的な活動など、 多様に過ごしている。軽度から重度になるほど一人当たりの滞在場
所数が減少していたことと考え合わせると、軽度では一人でいくつ もの空間を使い分けているのに対し、重度では人によって異なる空 間が生活の拠点として選択されており、それぞれの場所ごとに多様 な過ごし方が提供されていることが示唆される。

\section{6. 滞在場所にみる居方}

入居者の滞在の様態をより定性的に捉えるため、滞在場所におけ る入居者の居方注 13 に注目する。食事などのプログラムの場面、複 数で無為に過ごしている場面、一人で過ごしている場面など、いず れにも共通してみられた場面を除き、複数の入居者によって構成さ れる場面の居方を施設ごとに抽出した（表 4)。なお場面数は 15 分 ごとにプロットした入居者の生活場面からカウントした。

\section{(1) A 施設}

リビングでは、集まって一緒に喋る (22 場面・A1)、一緒にテ レビ（28 場面・A2）など、複数人で同じ行為を行う場面が多く見 られた。ただし、特定のユニットで特定の入居者によるものが多く を占めている。リビング内で複数の異なる行為があったのは 11 場 面（A3）であり、同じ行為を行う場面に比べ、多様な行為が混在 する場面はあまり多くなかった。他の集まりから少し離れて様子を 見る場面（A4）は 6 場面であり、それが見られたのは 1 つのユニッ トのみであった。リビング以外では、廊下のベンチで複数人で集まっ ている場面（A5）が 9 場面あった。はじめ一人でいたところに通 りかかった他の入居者が立ち寄ることで集まりが形成されることが 多く、リビング以外で偶発的に他者と関われる場所となっている。 しかしその数は多いとは言えず、全体に、メインのリビングで皆で 一緒に過ごす以外の居方は限られている。

\section{(2) B 施設}

リビングでは、滞在は多いが、食事や無為の場面を除くと取り上 げる場面はかなり減少する。集まって一緒に喋ったりテレビを見る のは合わせて 23 場面（B1）見られたが、そのうち 18 場面は比較 的自立度の高いショートステイ利用者が大半を占めるユニットにお けるものであった。リビング内で複数の異なる行為はほとんど見ら れなかった。廊下ベンチに座る場面は数多く見られ、リビングの様 子をみている場面が 60 場面（B2）、また複数で集まっている場面 は42 場面（B3）あった。そこには他ユニットの入居者が加わるこ ともある (28 場面)。リビングから少し離れて間接的に関わること のできる周辺的参加の場所として、またリビングよりも気軽に集 まったり積極的にコミュニケーションをとる場所として、多様な関 わりの場面が提供されていると言える。ユニットの外では、中央食 堂ホールで他者と居合わせる (6 場面・B4)、家族と一緒に過ごす （6 場面・B5）などがみられた。他ユニットに加わる場面と合わせ、 ユニット外に関わりを広げていく場面と言える。

\section{(3) C 施設}

各ユニットごとに、2 組ある続き間+ DK のうちの片方がメイン の滞在場所となっている。一緒に喋る $(10$ 場面・C1)、一緒にテ レビ（7 場面・C1）、一緒に作業（5 場面）など、皆で同じ行為を 行う場面よりも、フスマで連続する続き間+DKのそれぞれの場所 でそれぞれの過ごし方をしている場面が 42 場面 (C3) と、多くを 占める結果となった。空間がフスマによって分節化されながらも通 常開放されており、そこで好きな場所に滞在しながら、それぞれ孤 
表 3 入居者の滞在場所とそこでの行為

(要介護ごとに各人の行為頻度を 1 ユニットにまとめて表現した)

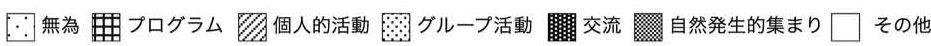

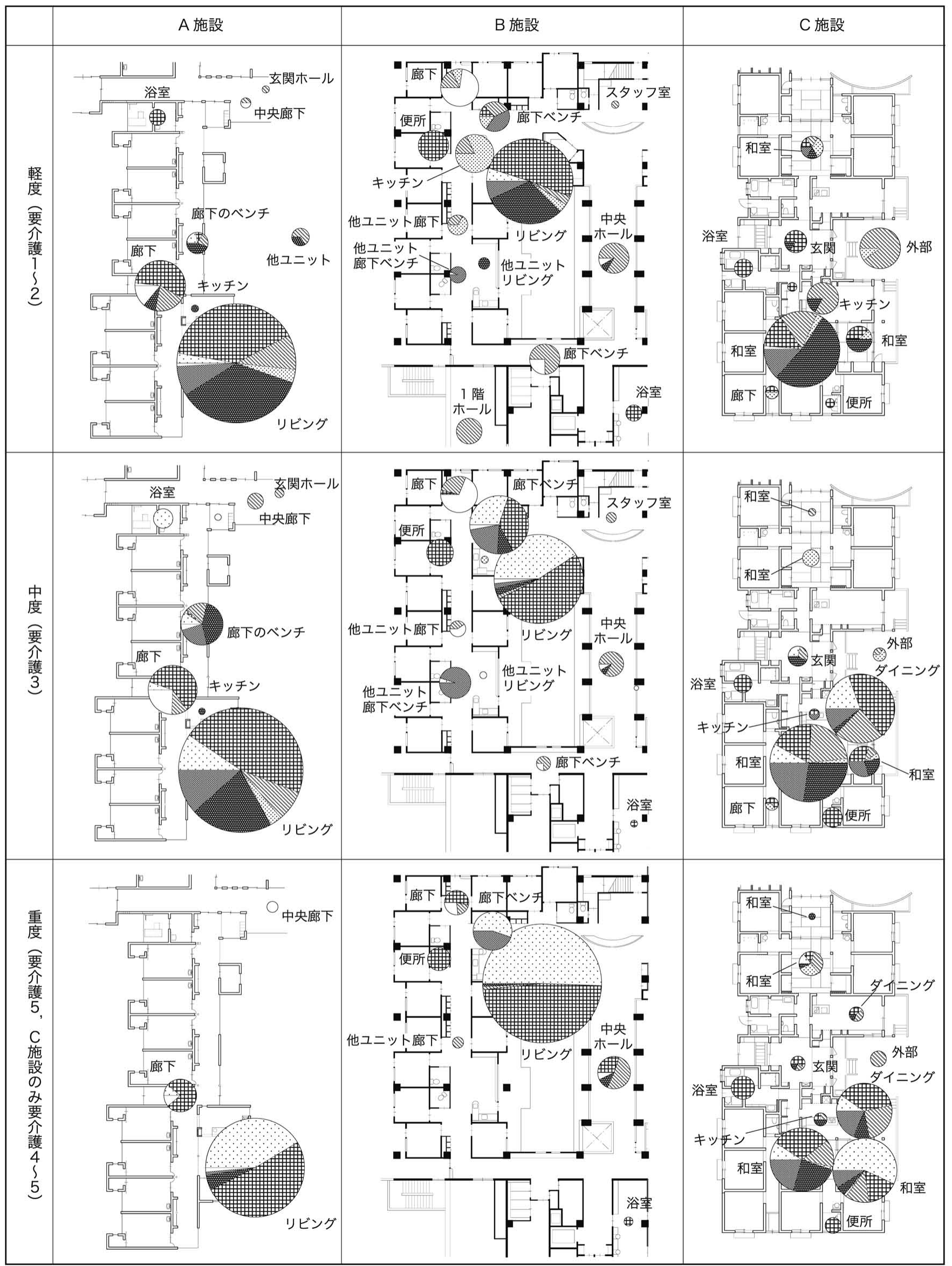


立せず互いに視線のやりとりが可能であることが特徵である（図 7)。ときには（重度を含む）入居者が自らフスマの開閉を行うこ とで、視線のやり取りや他者との関わりをコントロールする場面が 見られた（図 8)。一方、1つの和室に集まって異なる行為を行う 場面は多くない (3 場面・C4)。もう一力所の続き間では、数人で 一緒に作業（5 場面・C5）が見られるなど、メインの続き間とは 異なる場面が展開されている。

（4）特徵のある居方を支える場所

定性的な分析ではあるが、入居者の多様な居方の場面をもたらす 上で、全員集まって食事をするメインリビングがあるだけでなく、 以下のような場所の存在が寄与していると考えられる。

・メイン以外の場所の確保 : メインリビングとは別に、ユニット内 に入居者が自由に集える場所があることによって、滞在場所の選択 肢が増え、その時に応じた場所や居方を選択することが可能になる (A5・C5)。こうした場所は、最初から空間として設計されるだけ ででなく、廊下等を利用して適切な家具や道具などを設えることで も形成可能であろう。
・周辺的参加を促す場所：メインリビングに面したベンチなどは、 席の決まったリビングょりも、気軽に立ち寄れていつでも立ち去る ことのできる場所である $(\mathrm{A} 4 \cdot \mathrm{B} 2 \cdot \mathrm{B} 3)$ 。他者と直接会話をしな くても互いの存在を感じながら一緒に居られ、そしてリビングの様 子を少し離れて見ることができる。重度になって直接のコミュニ ケーションが困難になっても、間接的・周辺的に他者と関わりをも つことのできる場面が展開されうる主14。

・メインの場所の分節化：リビングなどのメインの滞在空間も、し きりや家具などで分節化することで、滞在場所の選択肢を増やし、 同時に多様な過ごし方を可能にする。空間の設えや見える風景やそ こに集まる人によって、それぞれに特徴のある滞在場所となり、そ れぞれの入居者が自分のお気に入りの場所を見つけることを可能に する (図 7)。滞在場所が固定されがちな重度の人にとっても、自 分に「固有の居場所 ${ }^{15}$ 」を見つけやすいと考えられる。

・多様なコントロールを可能にする仕組み：フスマで仕切られた続 き間は、フスマの開閉によって視線のやりとりや他者との関わりを 調整することができ、一つの空間に多様な空間の質がもたらされ、

表 4 各施設より抽出した主な居方の場面

(S : スタッフ、G : 外来者)

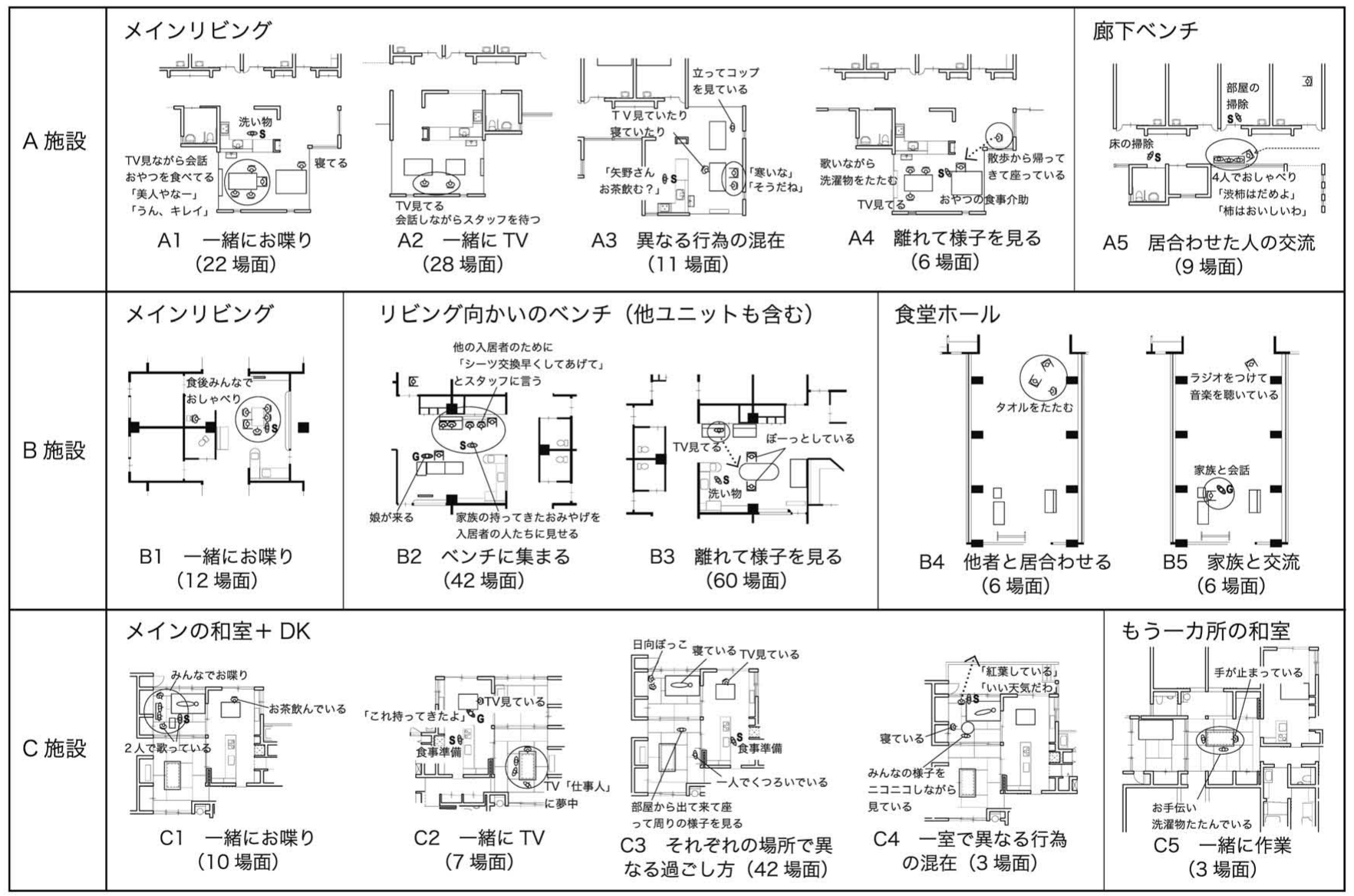

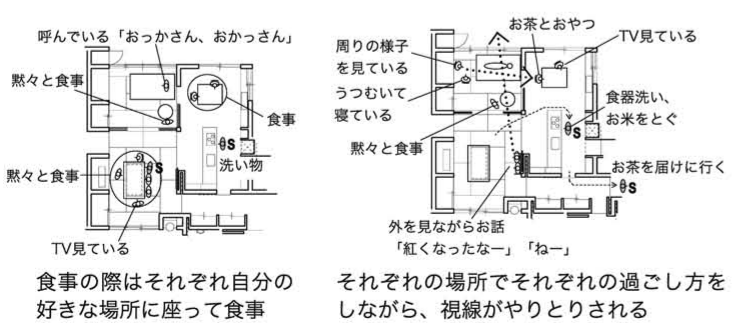

図 7 場所の分節化により可能となった過ごし方

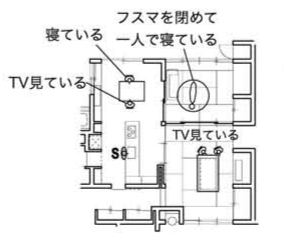

フスマを閉めてプライ ベート空間をつくる

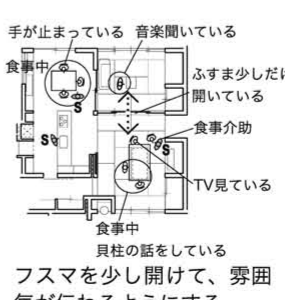

気が伝わるようにする

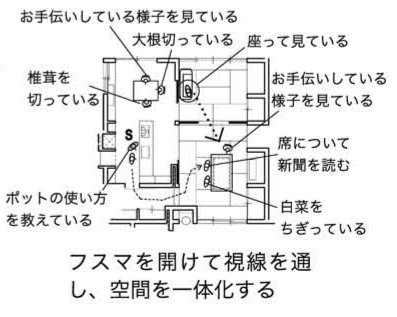

図８フスマの開閉による空間のコントロール 


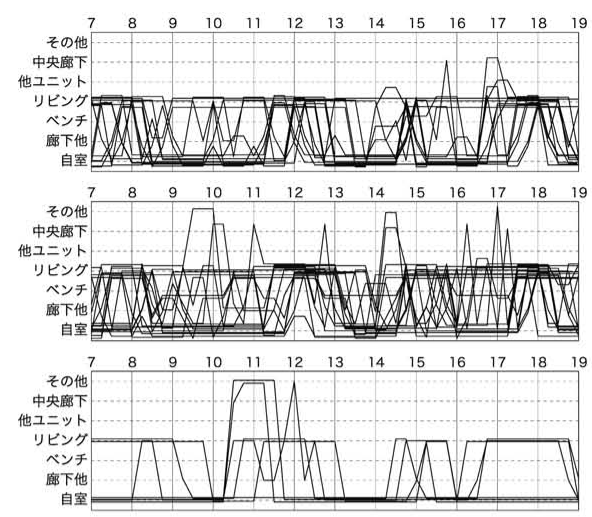

図 9 A 施設の入居者生活パターン

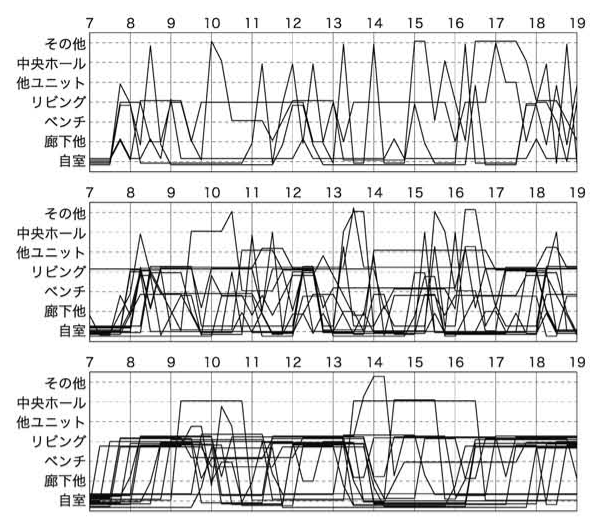

図 10 B 施設の入居者生活パターン

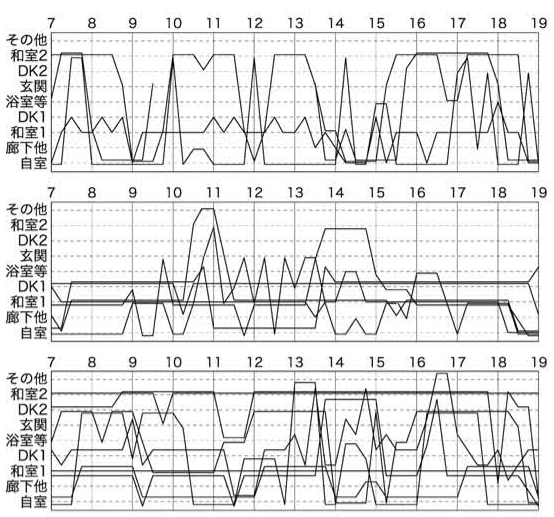

図 11 C 施設の入居者生活パターン いずれも、上：軽度（要介護度 $1 \sim 2$ ）、中：中度（要介護度 3 ）、下：重度（要介護度 $5 、 \mathrm{C}$ 施設のみ要介護度 4 ～5）

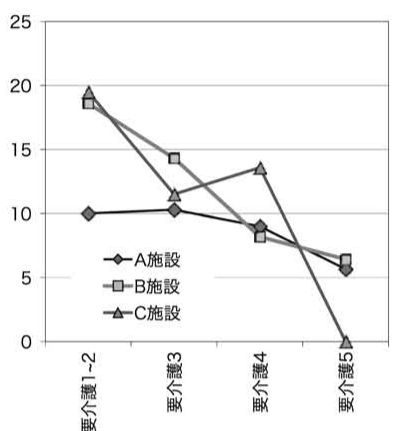

図 12 入居者の移動回数

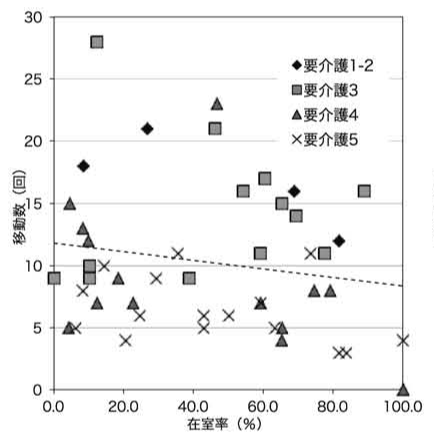

図 14 B 施設・移動数と在室率

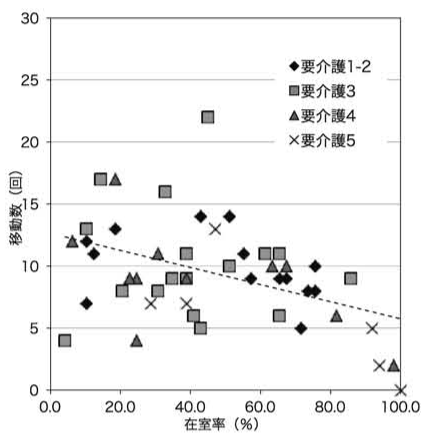

図 13 A 施設・移動数と在室率

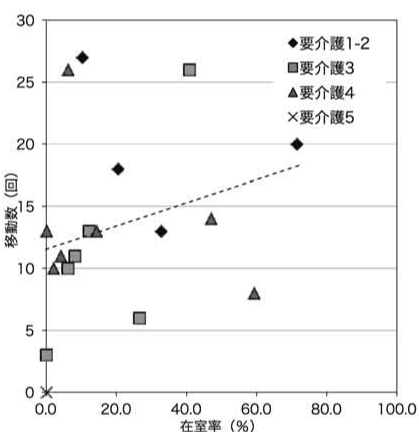

図 $15 \mathrm{C}$ 施設 $\cdot$ 移動数と在室率

表 5 在室率と移動回数の相関係数および回帰直線の勾配

\begin{tabular}{|l|c|c|r|r|r|r|}
\hline & \multicolumn{2}{|c|}{ A施設 } & \multicolumn{2}{c|}{ B施設 } & \multicolumn{2}{c|}{ C施設 } \\
\cline { 2 - 7 } & 相関係数 & 勾配 & 相関係数 & 勾配 & 相関係数: & \multicolumn{1}{|c|}{ 配 } \\
\hline 全体 & -0.426 & -0.07 & -0.167 & -0.03 & 0.254 & 0.09 \\
\hline 要介護1-2 & -0.403 & -0.04 & -0.144 & -0.02 & -0.280 & -0.06 \\
\hline 要介護3 & -0.059 & -0.01 & 0.077 & 0.01 & 0.745 & 0.39 \\
\hline 要介護4 & -0.584 & -0.08 & -0.509 & -0.08 & -0.029 & -0.01 \\
\hline 要介護5 & -0.747 & -0.77 & -0.354 & -0.03 & & \\
\hline
\end{tabular}

多様な過ごし方が可能となっている。自由な移動が困難になり滞在 場所が限定されてしまっても、そこでの過ごし方や他者との関わり 方が限定されず、本人によるコントロールを可能にしている (図 8)。 ・ ユニット外への生活の拡大 : ユニット型施設の課題として、比較 的ユニット内で完結しがちな入居者にとって、限定された人間関係 が煮詰まってしまう可能性が指摘されている注 16 。別ユニットを訪れ たり、ユニット外で他者と居合わせる場面（B4・5）は、ユニット 外に生活や関わりを広げてくれる役割をもつ。

\section{7. 入居者の生活パターン}

ここでは、多様な滞在場所が入居者の生活パターンに及ぼす影響 に注目する。一人ひとりの一日の生活における滞在場所の推移を、 要介護度別に重ねたものを図 9 〜 11 に示す。入居者数が異なるた め一概に比較はできないが、A施設では居室とリビングの往復を基 調として、比較的似通った生活パターンが多いように見受けられる。 B 施設では、軽度のうちはかなり個別性が感じられるが、重度にな るほど動きの少ない単調な生活になる傾向が見て取れる。C施設で は、滞在場所の数が多いこともあり、軽度ではもちろんのこと、重 度になっても一人ひとりの生活の個別性が感じられる。

ここで、生活の主体性や個別性をみる指標として、一人あたり の一日の場所の移動回数に着目する主 17 。平均回数を求めてみると、 $\mathrm{A}$ 施設では平均 9.3 回、B 施設では 10.3 回、C 施設では 13.4 回と なった。要介護度別にみると、いずれの施設も要介護度が高まるほ ど移動回数は減少の傾向にあることは共通しているが、その様相に は差がみられる（図 12）。A 施設では軽度から重度に至るまで少し ずつ減少するが、全体に要介護度による差は大きくない。B 施設は、 要介護度に応じて移動回数に明確に差が見られる。軽度入居者がか なり頻繁に滞在場所を移動しながら過ごしているのに対し、重度と なると移動が少なく、一力所に滞在する傾向が強くなる。C施設は、 移動回数 0 の要介護 5 の入居者 1 名を除くと、全体に移動回数が 多く、個人による回数のばらつきも大きい。かなり重度化しても、 自分なりに空間を移動しながら生活を組み立てていることが示唆さ れる。移動回数と滞在場所数との相関係数は、いずれの施設も正の 相関を示しており（相関係数：A 施設 $0.83 ， \mathrm{~B}$ 施設 $0.55 、 \mathrm{C}$ 施設 0.85)、滞在場所が多く形成されることで、それらの間を移動しな がらの生活が組み立てられていることが示唆される。

空間の移動回数と在室率との関係をみる（図 $13 \sim 15$, 表 5)。B· $\mathrm{C}$ 施設では在室率と移動回数との相関は見られなかったが、A 施設 では、在室率と移動回数にやや負の相関が認められた。とくに要介 護度が高いほど負の相関が強くなり、必要時以外は部屋に滞在し続 ける傾向のある入居者が少なくないことを示している。B施設では、 移動回数にかなりばらつきがあり、比較的軽度な入居者の中に在室 率・移動回数とも高い人が、重度の中に在室率・移動回数ともに低 い人が、それぞれかなり見られることが特徵である。C施設では全 体に在室率が低く、移動回数のばらつきはかなり大きい。共用空間 を中心にしながら、移動回数の多い人も少ない人もいるなど、個別 
性が強い。

$\mathrm{B} \cdot \mathrm{C}$ 施設の軽度入居者に一部みられた、在室率も高く移動回数 の多い生活は、居室を拠点としながらも他の空間を適宜行き交いな がら活用しており、主体的な生活の 1 つの現れと考えられる。共 用空間に多様な滞在場所が形成されていることが、こうした生活の 出現に寄与していると思われる。A 施設は、重度化が進んで自由な 空間の移動が困難になった場合、在室率が高くなる傾向があると言 え、個室にこもりがちの生活に結びつく可能性が高くなると考えら れる。共用空間に滞在しがちな B ・ C 施設の重度入居者の場合、そ れぞれの滞在場所での様態が生活を左右する。自分に合った滞在場 所を獲得できるのか、そこでどれだけ多様な過ごし方が許容される のか、という滞在場所の質がより重要な意味をもつと言えよう。

\section{8. まとめ}

（1） 3 施設における空間の滞在様態の違い

対象とした 3 施設はいずれも小規模な生活単位を実現している 施設であるが、入居者の滞在様態には少なから差がみられた。A 施設では、共用空間における滞在場所の数は最も少なかった。軽度 入居者では複数の滞在場所で多様な行為が見られたが、重度入居者 にとっては唯一の滞在場所であるリビングがプログラムと無為のみ に限定されるなど、質的にも選択肢がそしい状況となっている。B 施設は、開設後 10 年経過しかなり重度化が進んでいるが、軽度・ 重度ともにユニット内外に複数の滞在場所が形成されていた。重度 化した場合にはリビングは無為の時間が増えるものの、リビング以 外の空間で間接的に他者と関わりながら過ごしている様子が捉えら れた。C 施設は最も共用空間での滞在が長く、滞在場所の量・質と もに充実していた。軽度入居者は多くの滞在場所を使い分け、重度 入居者は自分なりの滞在場所を見つけ、いずれも多様な過ごし方、 多様な関わり方がなされていた。

（2）滞在様態が入居者の生活へ及ぼす影響

$\mathrm{A}$ 施設では重度化とともに生活が画一化・単調化する傾向がみら れた。とくに重度化するほど在室率と移動回数の相関が見られ、刺 激や関わりの少ないこもりがちの生活に結びつく可能性が指摘でき る。B 施設においても重度化するにつれ単調になる傾向はあるが、 共用空間を中心とした生活となっており、滞在場所において他の入 居者との接点は維持されていた。C 施設では、軽度から重度にいた るまで、在室率や移動回数などにばらつきが大きく、生活の個別性 が認められた。かなり重度化しても自分なりに空間を移動しながら 生活を組み立てていることが示唆される。共用空間内の多様な滞在 場所は、それぞれの場所における過ごし方の多様性をもたらすとと もに、主体的な空間の選択を可能にし、入居者の生活の質に大きく 反映されている可能性が指摘できる。

（3）多様な居方を促す場所

各施設の居方の場面を抽出した結果、仮説的ではあるが、ユニッ ト内のメインの共同生活室（リビング・ダイニング的空間）だけに 生活が集中するのでなく、メイン以外の場所や周辺的参加を促す場 所、メインの場所の分節化、多様なコントロール可能な仕組み、ユ ニット外への生活の広がりなどによって、より多様な居方の場面を もたらしうることを指摘した。こうした場所は、ただ滞在場所の選 択肢を増やすというだけでなく、多様な社会的関わりの形成を可能
にし、状況に応じた多様な過ごし方を可能にし、その人なりに生活 を広げていくことを可能にするのに大きく寄与している。比較的自 由に生活を構築しやすい軽度入居者のみならず、受動的になりやす い重度入居者にとって、主体性や個別性の発露を促し、生活の質に 大きく関わると言える。現状では居方の限定された施設であっても、 適切な場所に適切な設えを行ったり、スタッフの入居者に対する働 きかけなどによっても、多様な居方を可能にする場所の形成は可能 と思われる。そうした工夫が入居者の生活の質に寄与する余地は大 きいと言える。

（4）滞在場所の選択性と環境の許容性

滞在場所の選択肢を考える上で、軽度入居者と重度入居者とでは 「選択性」の意味が異なる可能性がある。軽度入居者にとっては、 さまざまな目的に応じた場所、そこでの活動や過ごし方や社会的関 わりが異なる場所の選択肢が多様に存在することによって、自分の 状況や要求に合わせてそれらを選択しながら使い分け、組み合わせ ながら、独自の生活を主体的に組み立てることが可能になると考え られる。これに対して重度入居者では、場所を自由に使い分けるこ とは困難になる。C施設にみられたように、重度化するとともに滞 在場所数は減少しても、それぞれの場所で多様な過ごし方ができれ ば、一人ひとりの生活の質は維持されるように思われる。メインリ ビングのような唯一の滞在場所だけが与えられるのではなく、多様 な過ごし方のできる場所がいくつか用意され、そこから自分なりに お気に入りの場所を見つけられることが、選択性として意味をもつ てくるのではないか。さらに、その場所においてフスマのような簡 単な仕掛けで他者との関わりや過ごし方がコントロールできるこ とも、重度入居者にとって選択性を高める方法の 1 つと思われる。 そして、このような「選択性」のある環境は、軽度から重度まで幅 広い人を受け入れることのできる許容性の高い環境と言える。それ は属性の異なる多様な人同士の共存を可能にし、特定の人同士に限 られないより幅広い社会的関わりをもたらしうると考えられる。

注

注 1）厚生労働省「平成 21 年度介護サービス施設・事業所調査」による。 この数值には、ユニット型 $18.7 \%$ と一部ユニット型 $10.2 \%$ を含んでおり、 定員ベースでの割合は $22.7 \%$ となる。

注 2) 文献 $1 \sim 16 、 18$ など。

注 3) 文献 9 による。

注 4) 文献 10 による。

注 5) 文献 11 参照。

注 6) 文献 12 〜 14 など。

注 7) 文献 15 参照。

注 8) 文献 16 参照。

注 9) 平成 17 年に、社会福祉施設等施設整備費補助負担金の制度が再編さ れ、国庫補助ではなく、都道府県または市町村による地域介護・福祉空 間整備等交付金による補助へと変更された。定員 30 人以上の特別養護老 人ホームは広域型施設として都道府県による補助事業とされ、市町村の 推進する定員 29 人以下の地域密着型施設とは区別される。

注 10) この滞在のしかたの要因の 1 つとして、居室内に便所を設けている かどうかによる可能性も考えられる。対象とした 3 施設のうち $\mathrm{A}$ 施設の み居室内に便所が設けられているため、排泄の際には基本的に居室にい ることになる。とくに自らの素早い移動が困難な入居者の場合には、ス タッフがその都度居室へ誘導する必要があり、本人の要望だけで居室の 滞在に結びついているとは一概に言えない。こうしたケアによる影響に ついては、別報で触れる予定である。 
注 11）文献 $1 \cdot 2$ を参考にし、以下のように分類した。「無為」：寝ている、 ぼんやししている、一人の世界に籠もっている、など。「プログラム行為」: 施設が一律に提供するサービスによる行為。食事、入浴、排泄、レクリエー ション等。「個人的活動」：一人で自主的に目的をもった活動・行動を行つ ているもの。「グループ活動」：何人かのグループで目的的な活動を行っ ているもの。複数でのお手伝いやサークル活動等。「交流」：会話等によ るコミュニケーションが行われている場面。「自然な集まり」: 自然に集 まってきて、それぞれ異なることをしながらも一緒にいる場面。

注 12)「リビング」や「廊下のベンチ」など、空間のまとまりごとに「滞在場所」 としてカウントした。リビング内での座席の変更などについては、同一 場所としてカウントしている。本文中に述べているょうに、全員に必ず 必須となる食事・入浴・排泄に伴う滞在場所はカウントから除外している。 ここでは「場所数」のみを検討するため、滞在場所での滞在時間や過ご し方による差異は考慮していない。

注 13）「居方」とは鈴木の提唱する概念で、「人間がある場所に居る様子や 人のいる風景を扱う枠組み」（文献 17）とされる。ここでは、ある生活 の場面に㧤いて入居者が他者とどのような関わりを保ちながらそこに居 るのか、という様態に着目し「居方」という用語を用いることとした。

注 14）このような滞在場所の重要性については、養護老人ホームを対象と した文献 6 でも指摘されている。

注 15) 文献 16 による。

注 16) 生活単位を小規模化することに伴うこうした課題は、文献 7 や 18 で も指摘されている。

注 17）文献 1 を参考に、居室に閉じこもり気味な生活や共用空間に滞在し 続ける生活は、いずれも主体的な生活とは言い難い場合が多く、主体的 に空間を使い分けながら生活している場合には空間の移動回数は多くな ると推測した。ただし、認知症による徘䧃症状がみられる入居者につい てはその限りでないため、カウントから除外している。

\section{参考文献}

1）槅弘志 : 特別養護老人ホームのケア環境と入居者の生活展開の比較一個 室型特別養護老人ホームの空間構成に関する研究 その 3 -, 日本建築 学会計画系論文集, No.548, pp.137-144, 2001.10

2）槅弘志 : 特別羔護老人ホーム共用空間におけるセミプライベート・セミ パブリック領域の再考一個室型特別養護老人ホームの空間構成に関する 研究 その 4-, 日本建築学会計画系論文集, No.557, pp.157-164, 2002.7

3）松原茂樹ほか：入居者に対する介護職員の関わりに関する考察〜ユニッ トケア型高齢者福祉施設における介護職員のケアのあり方に関する研究, 日本建築学会計画系論文集, No.561, pp.137-144, 2002.11

4）毛利志保ほか：小規模生活単位型特別養護老人ホームにおけるケア 体制を踏まえた空間特性に関する研究, 日本建築学会計画系論文集, No.572, pp.41-47, 2003.10

5）山口健太郎ほか：介護単位の小規模化が個別ケアに与える効果一既存特 別養護老人ホームのユニット化に関する研究（その1)-, 日本建築学会 計画系論文集，No.587，pp.33-40，2005.1

6）神吉優美ほか：高齢者居住施設における個室・ユニット化の意義および 問題点一個室・ユニット型養護老人ホームへの建替元事例を通して一, 日本建築学会計画系論文集, No.588, pp.47-54, 2005.2

7）神吉優美ほか：個室・ユニット型養護老人ホームにおけるユニット内共 用空間の利用実態一個室・ユニット型養護老人ホームにおける入居者の 空間利用実態 (その 1) - , 日本建築学会計画系論文集, No.592, pp.65$70,2005.6$

8) 孔相権ほか : 終末期を迎える場としての高齢者居住施設に関する考察一 個室ユニット化された介護療養型医療施設を事例として一, 日本建築学 会計画系論文集，No.607, pp.25-32，2006.9

9）石井敏：平面図分析にもとづくユニット型高齢者介護施設の平面計画の 実態と考察, 日本建築学会計画系論文集, Vol.76, No.661, pp.531$540,2011.3$

10）秋葉都子ほか：全国調査によるユニットケア実施施設の実態に関する考 察, 日本建築学会計画系論文集, Vol.77, No.671, pp.1-8, 2012.1

11）山田あすか：民家改修型認知症高齢者グループホームにおける空間構成 と入居者の滞在場所に関する研究, 日本建築学会計画系論文集, Vol.74,
NO.638, pp.781-790, 2009.4

12）厳爽ほか：グループホームにおける空間利用の時系列的変化に関する考 察〜「なじみ」からみた痴呆性高秢者のケア環境に関する研究（その1）, 日本建築学会計画系論文集，No.523，pp.155-161，1999.9

13）鈴木健二ほか：疾呆性高齢者グループホームにおける空間の構成と入 居者の生活・スタッフのケアの展開〜痴呆性高齢者のケア環境のあり方 に関する研究 (3), 日本建築学会計画系論文集, No.556, pp.169-176, 2002.6

14）黒木宏一ほか：認知症高齢者グループホームにおける入居者の過ごし方 からみた「生活の質」の評価—民家改修型の空間特性による過ごし方の 展開一, 日本建築学会計画系論文集, NO.618, pp.17-24, 2007.8

15）黒木宏一：認知症高齢者グループホームにおける重度入居者の過ごし 方の特性と空間の評価, 日本建築学会計画系論文集, Vol.73, No.629, pp.1449-1456, 2008.7

16）山田あすか：痴呆性高齢者グループホームの環境及び入居者の固有の 居場所とその変容に関する研究，日本建築学会計画系論文集，No.592, pp.93-100, 2005.6

17）鈴木毅ほか：JKKハウジング大学校講義録 I，小学館スクエア， 2000.10

18）山田あすか：小規模生活単位型特別養護老人ホームにおける空間構 成と入居者の生活様態の関係, 日本建築学会計画系論文集, Vol.73, No.629, pp.1477-1484, 2008.7

(2012年 9 月 2 日原稿受理，2013年 1 月29日採用決定） 